\title{
直立浮上式防波堤による現地津波防護効果に関する検討
}

\section{Protection Performance against Tsunamis due to Buoyancy-Driven Vertical Piling Breakwater}

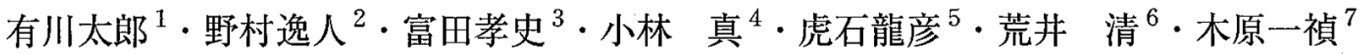 \\ Taro ARIKAWA, Hayato NOMURA, Takashi TOMITA, Makoto KOBAYASHI \\ Tatsuhiko TORAISHI, Kiyoshi ARAI, Kazuyoshi KIHARA
}

\begin{abstract}
This research investigates the protection performance against tsunami with the buoyancy- driven vertical breakwater by using the numerical simulations. Macro-Micro scale interlocked tsunami simulator named STOC (Storm surge and Tsunami simulator in Oceans and Coastal areas) has been applied to the series of simulations. Results of comparison of tsunami height in the Wakayama-shimotsu port and Fukura port due to Tokai, Tonankai and Nankai earthquakes indicates that this new breakwater decreases tsunami height and inundation area. Although the dissipating rate is depending on the position of this breakwater, the breakwater with $10 \%$ opening brings a $33 \%$ decrease in the maximum tsunami height.
\end{abstract}

\section{1.はじめに}

直立浮上式防波堤が提案され（山根ら，2005)，その 水理特性を大規模奏験および 3 次元数傎シミュレーショ ンを用いて検討した（有川ら，2007）。その結果，比較 的周期の長い津波に対する透過率特性，防波堤に作用す る波力，杭間流速などが明らかとなり，直立浮上式防波 堤の水理特性を示したが, 現地港湾における防護効果は 明らかではない。

そこで, 本研究では, 高潮・津波シミュレータ （STOC，富田ら 2005）を用いて，現地港湾に適用した 場合の津波効果を見ることを目標に，まず，実験との比 較検討により計算モデルの妥当性を検証し，次に，実験 では取り扱うことのできない長周期の波に対する氷理特 性を検討する. 最後に, 2 力所の現地港湾への適用を図 り，その防護効果を検討する。

\section{2. 計算モデル}

\section{（1）基礎方程式}

高潮・津波シミュレータは，STOC-ML，IC，VFの 3 つの連成モデルで構成されるが, 本研究では現地適用を 行う際の計算効率から，STOC-ML を用いることとした。

STOC-ML は，鉛直方向の運動方程式を静水圧近似 とし，水表面を鉛直方向に積分した連続式から決定する ことで，計算効率を良くし，㕕範囲において津波の伝播

\begin{tabular}{|c|c|c|}
\hline 1 正会員 & 博 (工) & (独法)港湾空港技術吥究所 主任研究官 \\
\hline 2 正会員 & & （独法）港鸱空港技術研究所 耐波研究室 \\
\hline 3 正会員 & 博(工) & （独法）港湾空港技術研究所 \\
\hline 4 正会員 & 修(工) & (株)大林組 土木技術本部 \\
\hline 5 & & 新日鉄エンジニアリンダ (株) \\
\hline 6 正会員 & 博 (工) & 東亜建設工業(株) \\
\hline 7 & & 三菱重工橋梁エンジニアリング(株) \\
\hline
\end{tabular}

計算のできる多層シミュレータである。

\section{(2) 浮上式防波堤の取り扱い}

直立浮上式防波堤（図-1）は，上部・下部鋼管からな り，通常は海底面下にあり，必要に応して空気を送り込 むことによって，鋼管が浮上する可動式の防波堤である. 図のように複数の杭管が並んでいる構造であり，下部鋼 管の厚みがあるため，管と管の間には隙間が生じる構造 となる. 現時点では管の直径は $2 \sim 3 \mathrm{~m}$ 程度が実用的 となる。

一方で，現地計算等の津波を現状の計算機能力で解析 するためには，計算格子の大きさは $10 \mathrm{~m}$ 程度となるため， 1 つの格子に鋼管が複数本入ることとなる. そこで, 浮上

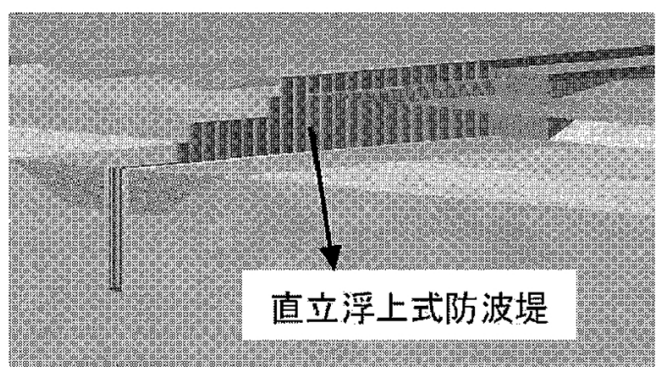

図-1 直立浮上式防波堤概念図

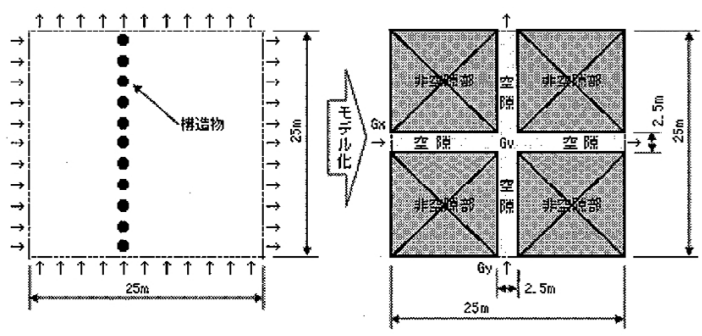

図-2 直立浮上式防波堤のモデル化 
式防波堤を図-2のように複数本まとめて空隙率として与 え，管と管の間に生じる隙間の効果を表現することとし た. 乱流モデルは，SGSモデルを組み込んでいる。

\section{3. 矩形水路における透過率の検討}

\section{（1）実験との比較検討}

モデルの妥当性を検討するために, 有川ら（2007）の 行った実験結果との比較を行う.実験は大規模波動水路 を用いて，約 $40 \mathrm{~cm}$ の鋼管を 7 本並べ，開口率 $5 \%$, 10\%，15\%で行った。ここでは, 有川ら（2007）の検 討と同じく, 鋼管 1 本を対象として計算領域を図-3の ように作成した. 水深は $2.0 \mathrm{~m}$ とし, 鉛直方向には, $(-2.5 \mathrm{~m},-2.0 \mathrm{~m},-1.0 \mathrm{~m},+1.0 \mathrm{~m},+2.5 \mathrm{~m})$ と 4 層にし, 水平方向の格子の大きさは， $1.0 \mathrm{~m}$ とし， STOC-MLを用いて検討した.

波浪条件は, 半周期が $20.0 \mathrm{~s}, 25.0 \mathrm{~s}, 26.8 \mathrm{~s}$ の 3 種 類, 波高 $0.8 \mathrm{~m}$ と $0.4 \mathrm{~m}$ を対象として, 実験と比較を 行った. 図-4 は, 波高 $0.40 \mathrm{~m}$, 半周期 $26.8 \mathrm{~s}$, 開口率 $15 \%$ 時系列の結果である. 実験と同じく入射波の津 波高さ $\left(\eta_{i \max }\right)$, 透過波の津波高さ $\left(\eta_{\mathrm{t} \text { max }}\right)$ を読み取り, 透過率を計算し，それを比較したものを図-5に示す。

図-5は横軸に開口率を, 縦軸に透過率を取ったもの である. 透過率 $10 \%$ のとき, ほぼ穾験と整合した結 果となっているが，透過率 $5 \%$ のときは笑験より透過し やすく，透過率 $15 \%$ \%とき実験より透過しにくい結 果であることがわかる.

直立浮上式防波堤は，鋼管からの反射と隙間を通ると きに生じる水平渦と縦渦により, エネルギーの伝達を抑 える構造であることが有川ら（2007）よりわかっており， その考察から今回の結果をみると，5\%の結果より，開

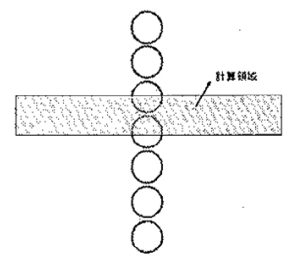

図-3 計算領域

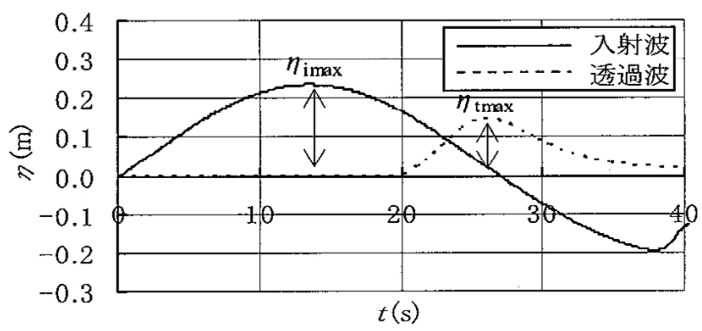

図-4計算による時系列波形の例

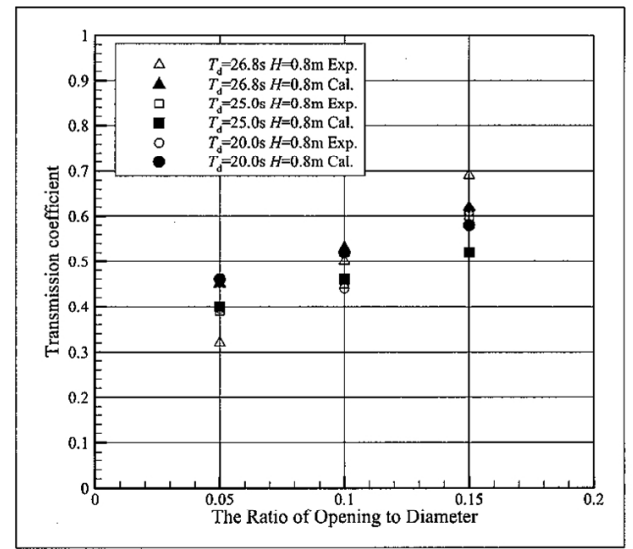

図-5 実験と計算との透過率の比較

口幅が小さくなってくると，本モデルでは渦や縮流効果 について，過小評価していることがわかる．また，15 \%の結果より，開口幅が大きくなると，実際に円柱であ るから角柱より反射効果が薄れるはずであるが，本モデ ルではその効果が入っていないため，その部分で過大評 価していることがわかる.それらの效果を取り入れたモ デル化は，今後の課題である.

\section{(2) 長周期に対する検討}

図-6のように，長さ $10 \mathrm{~km}$, 幅 $2.5 \mathrm{~km}$, 高さ $20 \mathrm{~m}$ の水路を用いて検討する. 図の左側から様々な周期の波 を入射させ，その透過率を検討する. 水平方向の計算格 子の大きさは現地適用計算時に用いる $25 \mathrm{~m}$ とした．鉛 直方向には, $(-10.5,-5,-2.5,0,2.5,+5.0$, $+10.0 \mathrm{~m} ）$ のように分割した. 側方境界を壁面，岸側 境界は開境界とした，直立浮上式防波堤は透過型の防波 堤であるため，岸側を閉めると水域面積と津波周期によ る流入・流出量とのバランスから背後地への影響は変わ ることが予想されるが，本研究は初期検討と位置付け， 岸側を透過させることとした。

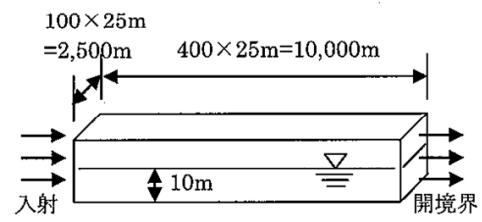

図-6 矩形水路形状図

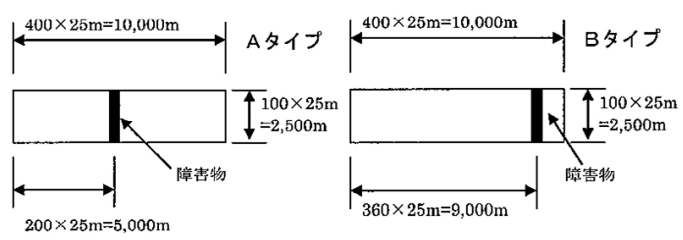

図-7 直立浮上式防波堤設置位置（平面図） 


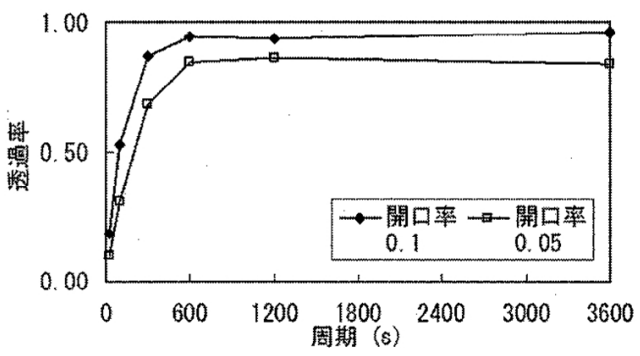

図-8 透過率の計算結果

水深は $10 \mathrm{~m}$ とし, 津波周期は，25，100，300，600， 1200,3600 秒, 波高は， $0.1 \mathrm{~m}$ とした．直立浮上式防

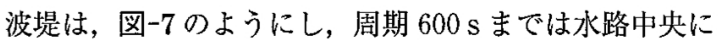

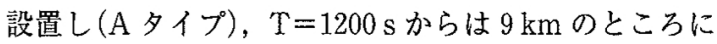

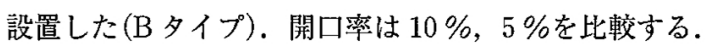

図-8は，透過率の結果をまとめたものである，岸側を 開境界としているため, 周期が長くなるに従って透過率 が大きくなっており，周期 $600 \mathrm{~s}$ を超えたあたりからほぼ フラットな状態になっていることがわかる．周期が長く なると, 全体的にゆっくりと水位上昇するようになるた め, 杭のようなものでは消波効果がないことが予想され, 計算結果はそれを意味しており，妥当な結果である.

有限振幅性が強くなり, 流速がより速くなれば, 実験 との比較でも考察したとおり，より詳細な縮流効果のモ デル化が必要であり，また，堰における流れのようにな るため, 浮上式防波堤背後に縦渦が生じるが，それによ りエネルギーが失われる機構のモデル化も必要であるも のの，両者ともに，エネルギーが現モデルよりも失われ るモデル化であり, それについては, 今後, 検討してい くものとする.

\section{4. 現地における効果の検討}

前述したとおり, 直立浮上式防波堤は透過型の防波堤 であり，岸側の水域面積と津波周期による流入・流出量 とのバランスにより, その湾内の防護効果が恋化する. そこで, 実際の現地に対して適用し, その防護効果を検 討する.ここでは, 福良港掞よび和歌山下津港を対象と した，福良港は南海モデルを，和歌山下津港は，東海・ 東南海・南海同時モデルを想定地震として用いた.

（1）福 良 港

\section{a) 計算条件および設置条件}

計算領域は 5 領域とし（図-9), 格子の大きさは, 第 1 領域が $1350 \mathrm{~m}$ ，第 2 は $450 \mathrm{~m}$ ，第 3 は $150 \mathrm{~m}$ ，第 4 は $50 \mathrm{~m}$, 第 5 は $25 \mathrm{~m}$ とした。潮位は, $+0.75 \mathrm{~m}$ とした。

直立浮上式防波堤の開口率は $10 \%$ とし, 図-10に示 す2つのタイプによる比較を行った. A タイプは B夕 イプよりも沖側に設置し，B タイプは島を防波堤のよう

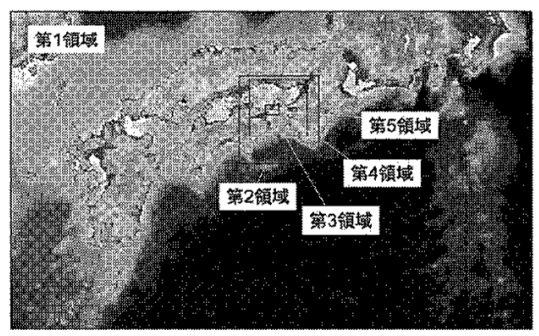

図-9 計算領域（福良港）

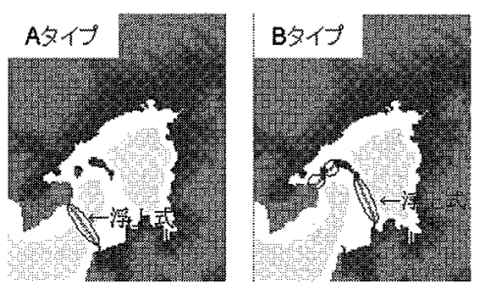

図-10 直立浮上式防波堤の設置場所（第 5 領域）
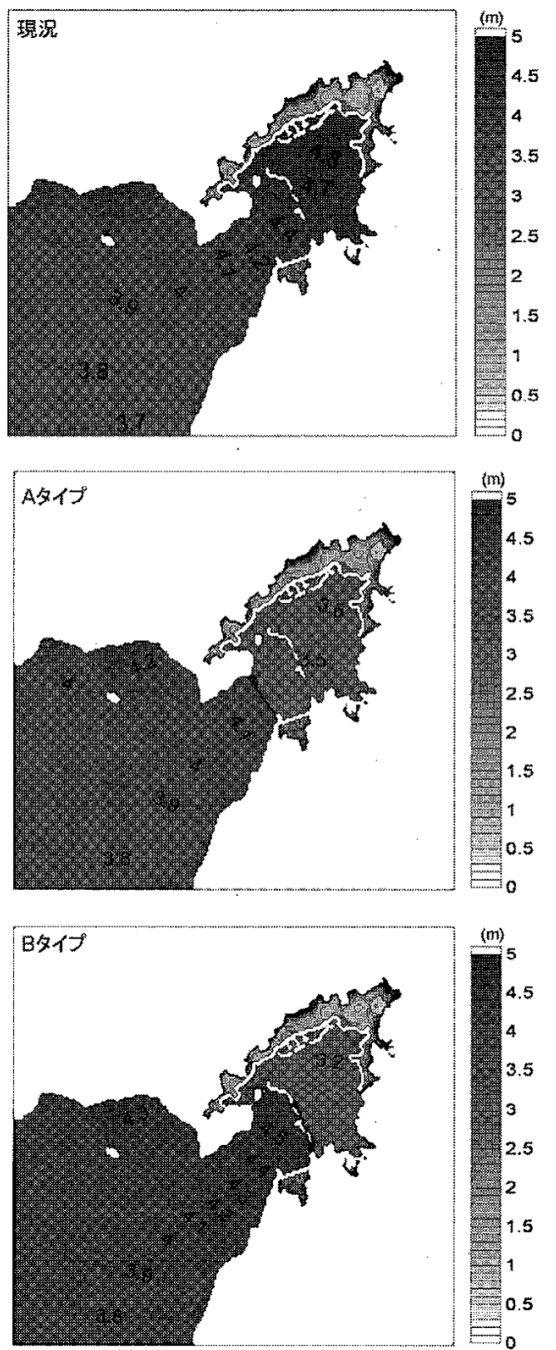

図-11 最大津波高の比較 
に利用して設置することとした。

\section{b) 計算結果}

図-11 は，現況，Aタイプ，Bタイプのそれぞれの津 波高の比較を行ったものである.

湾奥に到達している最大津波高の比較を行うと，現況 では $4.8 \mathrm{~m}, \mathrm{~A}$ タイプでは $3.6 \mathrm{~m}, \mathrm{~B}$ タイプでは $3.2 \mathrm{~m}$ となっている. B タイプは A タイプよりも効果があり, 最大津波高を $33 \%$ 減少させている.A タイプと B タイ プに効果の差が生じたのは，直立浮上式防波堤の背後の 水域面積の影響と考えられ，背後水域と津波周期が直立 浮上式防波堤の效果に及ほす影響を検討する必要がある.

\section{（2）和歌山下津港}

a) 計算条件

計算領域は 5 領域（図-12）とし，各領域の格子サイ ズは福良港と同じとした。潮位は， $+1.90 \mathrm{~m}$ で行った。 時間間隔は 0.5 秒，図-13のように港口に浮上式水門を 設置した

計算ケースは, 表-1のように現況のケースに対して， 開口率 $10 \%$ ，5\%の直立浮上式防波堤を設置したケース 1 抢よびケース 2, そして，既存防波堤を $200 \mathrm{~m}$ 延長した 上で $5 \%$ の開口率の直立浮上式防波堤を設置したケース 3

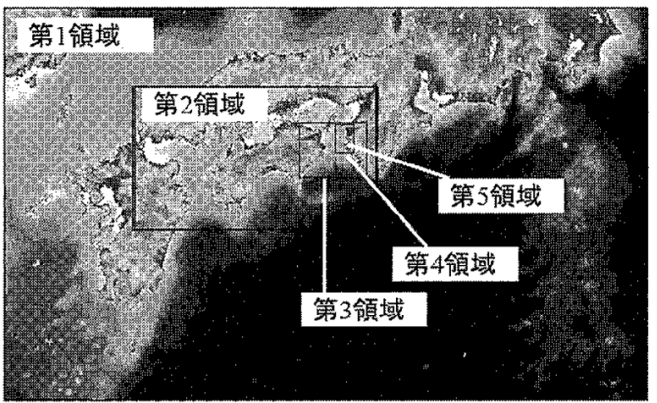

図-12 計算領域（和歌山県下津港）

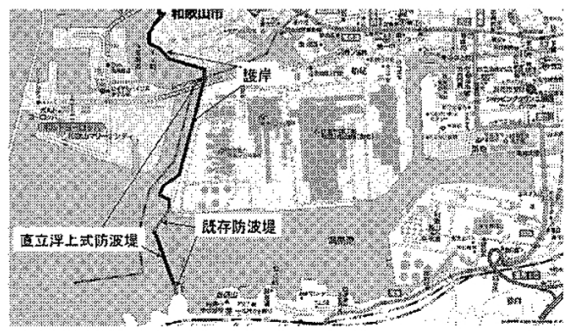

図-13 直立浮上式防波堤の設置条件

表-1 計算ケース

\begin{tabular}{|c|c|c|c|c|}
\hline ケース名 & 護 岸 & 既存防波堤 & & 式(開口率) \\
\hline ase0（現況） & 現況高さ & 天端 現況 & & $\begin{array}{ll}\text { 無し } \\
\end{array}$ \\
\hline Case 1 & 無限高さ & 天端 無限 & 天端 & 無限 $(10 \%)$ \\
\hline Case 2 & 無限高さ & 天端 無限 & 天端 & 無限( \\
\hline Case 3 & 無限高さ & $200 \mathrm{~m}$ 延長, 天端無限 & 天端 & 無限 ( $5 \%)$ \\
\hline
\end{tabular}

とした. 直立浮上式防波堤の防護効果をみるため, case1 〜 case3 は，既存防波堤からの越波しない条件とした.

\section{b) 最大津波高の検討}

最大津波高の比較を図-14に示す. 現況から case1, case2, case 3 になるに従って湾奥の最大津波高は小さ くなっていることがわかる.しかし，同時に反射してい
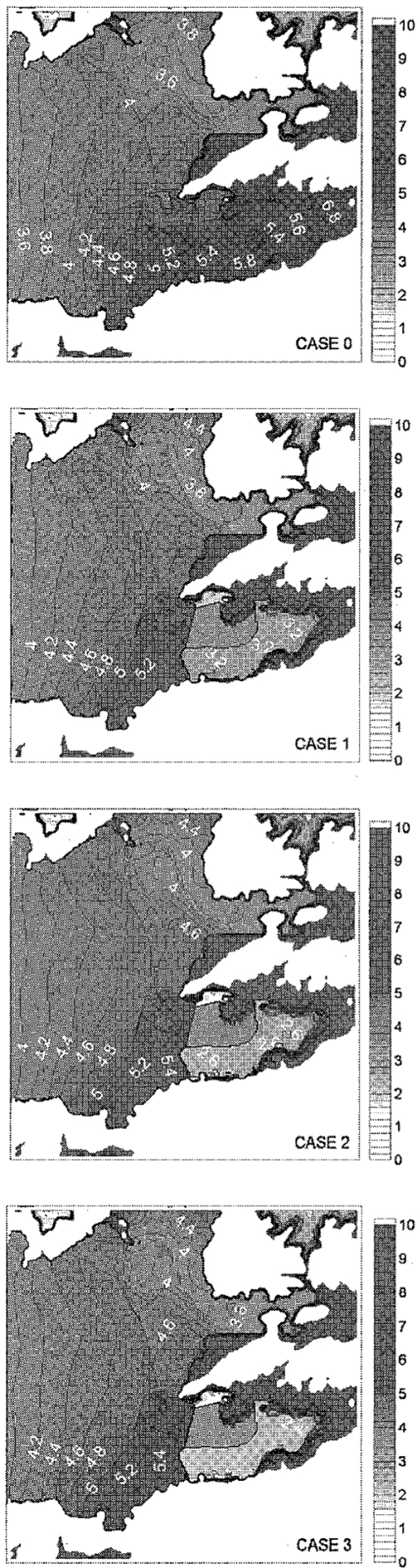

図-14 各ケースの最大津波高の比較 
るため，周辺の津波高が $40 \mathrm{~cm}$ 程度大きくなって抢り， 影響が及んでいることがわかる.

次に, 港内の護岸の高さを無限にし, 港内平均水位の 比較を行った，図-15 は，各ケースにおける水位の変化 量を示すものである。つまり港全体水位の単位時間あた りの増減を示している，よって，この量を各時刻で足し 合わせることによって，港内での蓄積量を知ることがで きる（図-16）。これを見ると case1〜 case3になるに従 い，港内から津波の流入は減少するものの，反対に港内 からは流出しにくくなっていることがわかる，そのため， case 3 では，港内水位が最大になる時刻は，105 分時に 来襲する最大津波時ではなく，その後に続く津波の来襲 時であり，若干の遅れが生じている。

図-17に港全体水位の全来襲津波の中での最大值の比 較を行ったものを示す．これを見ると，現況との比較か ら $10 \%$ の防波堤を設置した効果は約 $33 \%$ あることが わかる。福良港の B 夕イプと同程度であった，ただし， 護岸や既存防波堤の天端の影響も大きい.

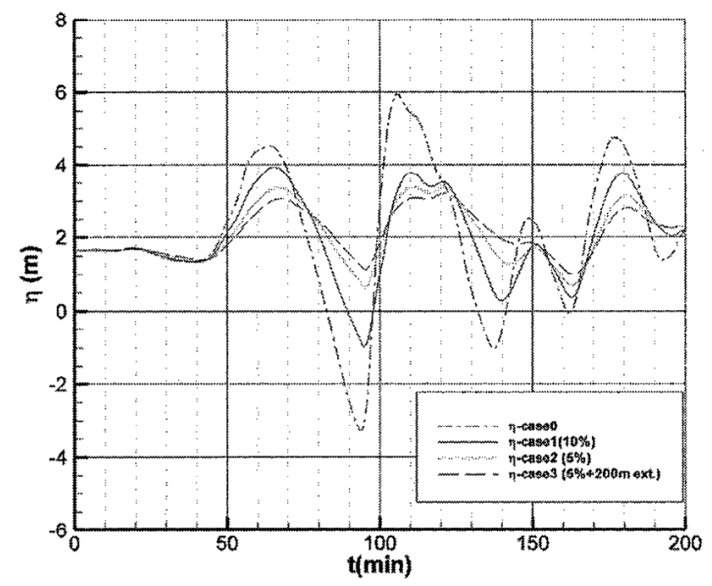

図-15 港全体水位の単位時間あたり増減

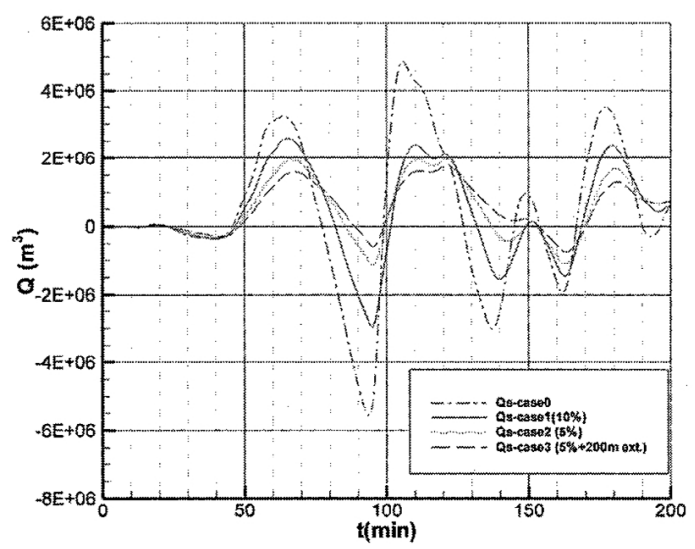

図-16 港内の蓄積量の変化

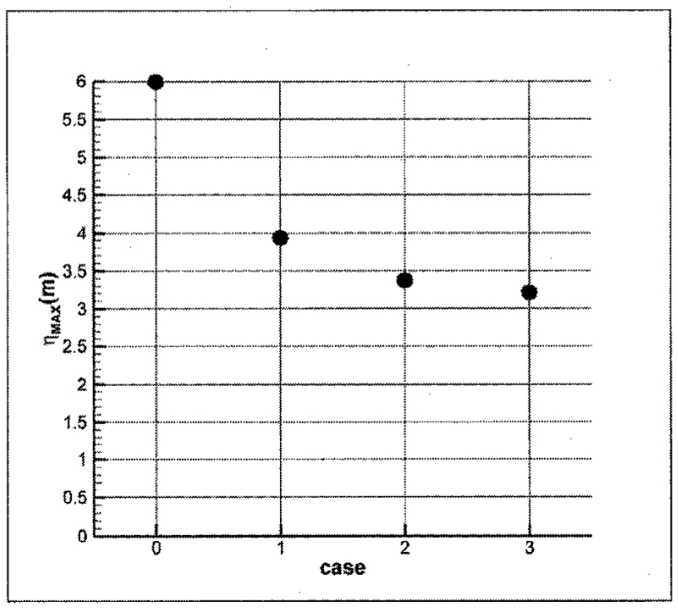

図-17 港全体平均水位の最大値

全体として計算結果より，設置場所によって多少の変 化はあるものの，約 $30 \%$ 程度の波高減衰が見込まれる。 つまり，波のエネルギーとして考えると半分程度となる ため，単に浸水範囲を軽減するだけでなく，構造物にも たらす破壊エネルギーの軽減にもなる，さらに，最大水 位となる時間を䐅らせることで避難時間を稼ぐことがで きる等，防災効果を持つ防波堤であることがわかる.

\section{5. まとめ}

直立浮上式防波堤の津波に対する防護効果の算定方法 について数值シミュレーションを用いて検討した，実験 結果と比較検討したところ, 縮流効果の過小評価, 円柱 としてのモデル化に対してさらに詳細な検討が必要なも のの，傾向や透過率の大きさは定量的にも妥当な結果を 得た。さらに, 長周期の波に対して検討したところ, 定 性的に妥当な結果が得られた。 そこで，本モデルの現地 への適用計算を試みたところ，直立浮上式防波堤による 津波に対する防謢効果を定量的に明からにした，今後は， 設置位置などによる効果の変化について検討する.

\section{参 考 文 献}

富田孝史・秝沼太郎 (2005)：海水流動の 3 次元性を考虑した高 潮・津波数值シミュレータSTOC の開発と津波解析への 適用, 港空研報告, 第 44 巻第 2 号

有川太郎・ 中野史丈·野村逸人 -下迫健一郎・ 小林 真・虎 石龍彦 - 荒井 清 - 木原一禎 (2007)：直立浮上式防波堤の 津波・風波に対する水理特性について, 港空研資料, No. 1156.

山根隆行 - 有川太郎 - 伊藤政人 - 増山挀也 - 龟井幸雄 - 宮坂 政司 (2005): 囬立浮上式防波堤の開発，海洋開発論文集， vol. 21 , p. $115-120$. 